\title{
Effect of deformation nanostructuring of nickel and copper on ion sputtering with a focused gallium ion beam with an energy of $30 \mathrm{keV}$
}

\author{
R. K. Khisamov ${ }^{1, \dagger}$, K. S. Nazarov ${ }^{1}$, A. V. Irzhak ${ }^{2,3}$, R. U. Shayakhmetov ${ }^{1}$, I. I. Musabirov ${ }^{1}$, \\ R. R. Timirayevev, ${ }^{1,4}$ Y. M. Yumaguzin ${ }^{1,4}$, R. R. Mulyukov ${ }^{1,4}$ \\ ${ }^{\dagger}$ r.khisamov@mail.ru
}
${ }^{1}$ Institute for Metals Superplasticity Problems RAS, 39 Stepan Khalturin St., Ufa, 450001, Russia ${ }^{2}$ Institute of Microelectronics Technology and High-Purity Materials RAS, 6 Institutskaya St., Chernogolovka, 142432, Russia
${ }^{3}$ National University of Science and Technology MISiS, 4 Leninsky Av., Moscow, 119049, Russia ${ }^{4}$ Bashkir State University, 32 Zaki Validi St., Ufa, 450076, Russia

\begin{abstract}
Ion sputtering of nanostructured, with an average grain size of about $200 \mathrm{~nm}$, fine-grained, with an average grain size of $5 \mu \mathrm{m}$, and coarse-grained nickel and copper samples with a focused gallium ion beam with an energy of $30 \mathrm{keV}$ has been investigated. As a result of ion sputtering with a focused ion beam, sputtered (etched) areas with different reliefs have been formed on the surface of the samples. It is shown that the relief formed on the surface of the sputtered area in the process of ion sputtering depends on the grain size of the sample. With a grain size corresponding to the fine-grained or coarsegrained states, sputtering occurs unevenly. With a grain size corresponding to the nanostructured state, sputtering occurs relatively evenly. For the energy of gallium ions $30 \mathrm{keV}$, the dependence of the maximum relief height $R_{\max }$ of the sputtered surface on the grain size $d$ of the metal in the range from nanostructured to fine-grained states is established: $R_{\max } \approx 0.1 d$. The sputtering yields of nickel and copper samples with different grain sizes are determined. The value of the sputtering yields has been estimated from the measurements of profilograms of the sputtered areas using scanning probe microscopy. It has been established that the deformation nanostructuring of a metalleads to a decrease in the emission of atoms from its surface when bombarded with gallium ions with an energy of $30 \mathrm{keV}$. Thus, the sputtering yield of coarse-grained nickel and copper is $4.8 \pm 1.5$ and $4.9 \pm 1.3$ atom/ion, respectively, of fine-grained nickel $-4.1 \pm 1.6$ atom/ion, nanostructured nickel and copper $2.0 \pm 0.5$ and $2.1 \pm 0.2$ atom/ion, respectively. On the basis of the sputtering mechanism in the linear cascade regime, an analysis of the reasons for the decrease in the sputtering yield of the metal as a result of its deformation nanostructuring is made.
\end{abstract}

Keywords: deformation nanostructuring, focused ion beam, sputtering yield.

УДК: $537.534 .8,620.186$

\section{Влияние деформационного наноструктурирования никеля и меди на ионное распыление фокусированным ионным пучком ионами галлия энергией 30 кэВ}

\author{
Хисамов Р.Х. ${ }^{1, \dagger}$, Назаров К. С. ${ }^{1}$, Иржак А. В. ${ }^{2,3}$, Шаяхметов Р. У. ${ }^{1}$, Мусабиров И. И. ${ }^{1}$, \\ Тимиряев Р. Р. ${ }^{1,4}$, Юмагузин Ю. М., ${ }^{1,4}$, Мулюков Р. Р. ${ }^{1,4}$ \\ ${ }^{1}$ Институт проблем сверхпластичности металлов РАН, ул. Степана Халтурина, 39, Уфа, 450001, Россия \\ ${ }^{2}$ Институт проблем технологии микроэлектроники и особочистых материалов $\mathrm{PAH}$, \\ ул. Институтская, 6, Черноголовка, 142432, Россия \\ ${ }^{3}$ Национальный исследовательский технологический университет МИСиС, Ленинский пр., 4, Москва, 119049, Россия \\ ${ }^{4}$ Башкирский государственный университет, ул. Заки Валиди, 32, Уфа, 450076, Россия
}


Исследовано ионное распыление наноструктурных, со средним размером зерен около 200 нм, мелкозернистых, со средним размером зерен 5 мкм, и крупнозернистых образцов никеля и меди фокусированным ионным пучком ионами галлия с энергией 30 кэВ. В результате ионного распыления фокусированным ионным пучком на поверхности образцов образованы распыленные (протравленные) участки с различным рельефом. Показано, что рельеф, формирующийся на поверхности распыленного участка в процессе ионного распыления, зависит от размера зерен образца. При размере зерен, соответствующим мелкозернистым или крупнозернистым значениям, распыление происходит неравномерно. При размере зерен, соответствующим наноструктурным значениям, распыление происходит относительно равномерно. Для энергии ионов галлия 30 кэВ установлена зависимость максимальной высоты рельефа $R_{\max }$ распыленной поверхности от размера зерен $d$ металла в диапазоне от наноструктурного до мелкозернистого: $R_{\max } \approx 0.1 d$. Определены коэффициенты распыления образцов никеля и меди с различным размером зерен. Величину коэффициентов распыления оценили из измерений профиллограмм распыленных участков методом сканирующей зондовой микроскопии. Установлено, что деформационное наноструктурирование металла приводит к снижению эмиссии атомов с его поверхности при бомбардировке ионами галлия энергией 30 кэВ. Так, коэффициент распыления крупнозернистого никеля и меди равен $4.8 \pm 1.5$ и $4.9 \pm 1.3$ атом/ион, соответственно, мелкозернистого никеля $-4.1 \pm 1.6$ атом/ион, наноструктурного никеля и меди $-2.0 \pm 0.5$ и $2.1 \pm 0.2$ атом/ион, соответственно. На основе механизма распыления в режиме линейных каскадов проведен анализ причин снижения коэффициента распыления металла в результате его деформационного наноструктурирования.

Ключевые слова: деформационное наноструктурирование, фокусированный ионный пучок, коэффициент распыления.

\section{Introduction}

Ion sputtering, i.e. the emission of neutral atoms from the surface of a material when it is bombarded with accelerated ions, occurs during the operation of many ionic devices, such as ion sources, gas lasers, light sources, etc. Such sputtering can distort the operation of devices. So, for example, in case of a cold cathode, which is an electron emitter in these devices, when sputtering changes the surface relief, the emission efficiency and durability of the cathode are reduced. Sputtered atoms can also change the optimal pressure of the working gas, which can lead to a decrease in the efficiency of the device.

Traditionally, a reduction of the sputtering yield of a cathode material is achieved by varying its chemical composition. At the same time, not only the chemical composition of the material, but also its microstructure, in particular, grain size and crystallographic texture, has an influence on the sputtering yield [1-9].

Deformation nanostructuring is one of the attractive methods for producing nanostructured materials with an average grain size of 100-200 nm. This method, in comparison with other known methods of nanostructuring, allows obtaining bulk nanostructured materials without residual pores and impurities. To date, many physicmechanical properties of nanostructured materials obtained by the deformation method of nanostructuring have been studied [10-14].

However, studies of the effect of deformation nanostructuring of the material on its ion sputtering, in particular, on the sputtering yield and the relief formed on the surface of the nanostructured material as a result of ion sputtering, have not been carried out. In this regard, the purpose of the work was to study the effect of the average grain size of a metal in the range corresponding to states from the nanostructured to coarse-grained ones on its sputtering yield and the relief formed on the metal surface as a result of ion sputtering.

\section{Materials and methods}

Metals with an fcc lattice - nickel (99.9\%) and copper (99.9\%) - were used as materials for studies. Deformation nanostructuring was carried out by the method of highpressure torsion (HPT) [15-19]. HPT was performed at a pressure of $6 \mathrm{GPa}$ on Bridgman anvils with a number of revolutions of 10 at room temperature. The samples obtained by the HPT had the form of disks with a diameter of $10 \mathrm{~mm}$ and a thickness of $0.2 \mathrm{~mm}$. Discs for studies with a diameter of $3 \mathrm{~mm}$ were cut out from each obtained sample at a distance of $3 \mathrm{~mm}$ from its center (Fig. 1). One of the disks of each metal remained as a nanostructured sample, the remaining disks were annealed to obtain a fine-grained and coarse-grained structure in them. Nickel disks were annealed at temperatures of 150,500 , and $800^{\circ} \mathrm{C}$, copper disks at $900^{\circ} \mathrm{C}$. To ensure a smooth shape, the surface of the samples was subjected to mechanical polishing using sandpapers with grit numbers increasing up to 4000 and subsequent electrochemical polishing. Nickel samples were polished in a solution of $90 \% \mathrm{C}_{4} \mathrm{H}_{9} \mathrm{OH}+10 \% \mathrm{HClO}_{4}$

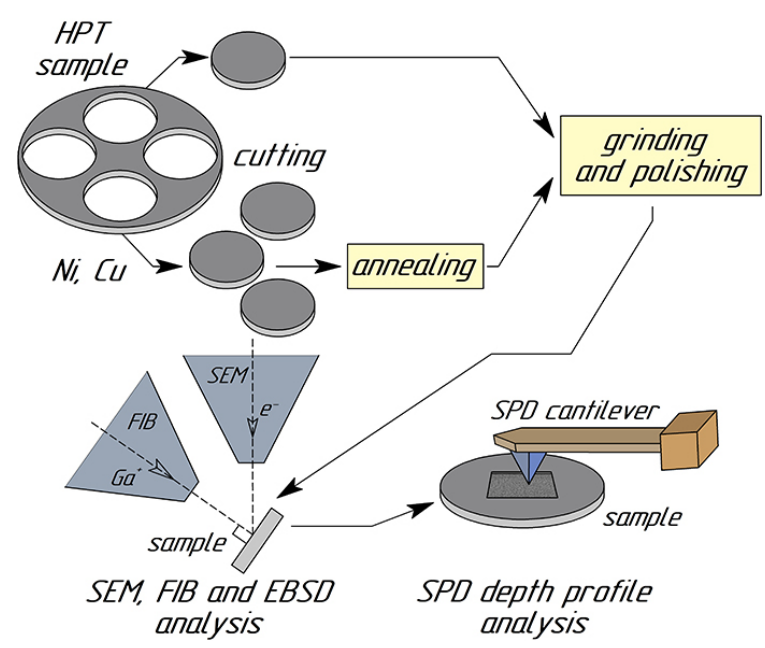

Fig. 1. The scheme of investigations. 
at $U=40 \mathrm{~V}, J=35-45 \mathrm{~mA}, T=23^{\circ} \mathrm{C}$, copper samples $20 \% \mathrm{H}_{3} \mathrm{PO}_{4}+80 \% \mathrm{H}_{2} \mathrm{O}$ at $U=12 \mathrm{~V}, J=0.65 \mathrm{~mA}, T=23^{\circ} \mathrm{C}$. After that, the samples were cleaned in an ultrasonic bath in ethanol. The surface roughness of the samples was determined using a NanoScan-3D scanning probe microscope (Tisnum, Russia). The roughness parameter $R_{z}$ of the samples did not exceed $40 \mathrm{~nm}$. The microstructure of the samples was examined using a Mira 3LHM scanning electron microscope (Tescan, Czech Republic) equipped with an EBSD analyzer.

For ion sputtering of the samples, the focused ion beam method was used, which is one of the modern methods to study the ion sputtering [20-28]. This method allows you to locally sputter the surface of the material with constant specified parameters of the ion beam.

Ion sputtering was performed with focused gallium ion beam at currents of 0.8 and $2.7 \mathrm{nA}$, an energy of $30 \mathrm{keV}$ for 30 minutes using a Strata FIB 205 scanning ion microscope (FEI, Netherlands). The angle between the beam and the sample plane was set to $90^{\circ}$. Using the software, a region of $40 \times 40 \mu \mathrm{m}$ was defined. The sputtered areas on the samples were examined with a Mira 3LHM scanning electron microscope and a NanoScan-3D scanning probe microscope (Tisnum, Russia). The sputtering yield and the relief formed on the surface of the sample as a result of sputtering was estimated from the measurements of the profilograms of the selected region along five lines.

\section{Results and discussion}

As a result of HPT a nanostructure with an average grain size $d=180 \mathrm{~nm}$ was formed in nickel samples. Analysis of the spectrum of misorientations of the grain boundaries of nanostructured (NS) samples showed that more than $70 \%$ of the boundaries are high angle. Annealing of the NS sample at $150^{\circ} \mathrm{C}$ led to an increase in the average grain size to $d=300 \mathrm{~nm}$. As a result of annealing at $500^{\circ} \mathrm{C}$, a fine-grained structure with an average grain size $d=5 \mu \mathrm{m}$ was formed in the sample. After annealing at $800^{\circ} \mathrm{C}$, a coarse-grained structure with an average grain size $d=30 \mu \mathrm{m}$ was observed in the sample. HPT of copper samples led to the formation of a nanostructure with an average grain size of $260 \mathrm{~nm}$; after annealing at $900^{\circ} \mathrm{C}$, a coarse-grained structure with an average grain size of $180 \mu \mathrm{m}$ was formed in the sample.

The impact of a focused ion beam led to the sputtering of the sample surface (Fig. 2). The relief on the surface of the sputtered areas on samples with different grain sizes varied. For example, on the NS samples of nickel and copper, the surface was sputtered relatively evenly (Fig. $2 \mathrm{a}, \mathrm{b}, \mathrm{c}$ ), the maximum relief height $R_{\max }$ (roughness parameter) did not exceed $30 \mathrm{~nm}$ (Fig. 3c). The surface was sputtered unevenly on the fine-grained nickel sample (Fig. $2 \mathrm{~d}$ ), $R_{\max } \approx 300 \mathrm{~nm}$ (Fig. $3 \mathrm{c}$ ). On the coarse-grained nickel sample, the surface was also sputtered unevenly (Fig. 2 e). On the coarse-grained copper sample, the surface was sputtered relatively evenly due to the fact that the sputtered area contained only one grain (Fig. 2f). For the nanostructured and the fine-grained samples, the dependence of the maximum relief height $R_{\max }$ on the grain size can be described by the relation: $R_{\max } \approx 0.1 d$.

Measurements of profilograms of the sputtered areas using scanning probe microscopy showed that the average values of the depth of the sputtered areas for samples with different grain sizes varied (Fig. 3). The average depth of the sputtered areas on the NS samples is lower than the average depth of the areas on the fine-grained and coarse-grained samples (Table 1). Therefore, all other things being equal, in particular, the area and time of sputtering, the average volume of the sputtered material, and, accordingly, the average sputtering rate from the NS samples is lower than the average sputtering rate from the samples with a large grain size. In its turn, the sputtering rate of a material is directly proportional to its sputtering yield. Consequently, the sputtering yield of the NS sample is lower than the yields of the fine-grained and the coarse-grained sample.

Evaluation of the sputtering yield of $Y$ samples was determined by the formula

$$
Y=\frac{N_{a} \cdot e \cdot \rho \cdot S \cdot h}{A \cdot I \cdot t}
$$

where $N_{a}$ is the Avogadro number, $e$ is the electron charge, $\rho$ is the density, $A$ is the molar mass, $I$ is the ion current, $S$ is the area, $h$ is the average depth of the region, $t$ is the sputtering time [29]. Quantitative estimates indicating lower values of the sputtering yield of the NS samples compared to those of samples with a large grain size are presented in Table 1.

Ion sputtering of a metal at an energy of incident ions of $30 \mathrm{keV}$ occurs in the linear cascade collision regime [29-31]. At such energies, the projective penetration depth of gallium ions in nickel and copper samples is about ten nanometers. Bombarding ions transfer kinetic energy to atoms, due to which the latter are displaced from their equilibrium positions. Displaced primary atoms create a cascade of collisions with other atoms, which result in the formation of secondary, tertiary, etc. displaced atoms, which moving along the crystal lattice of a metal, can reach its surface, overcome the surface barrier, and leave the metal, i. e. to be sputtered.

An NS metal contains a high concentration of defects (vacancies, dislocations) and a large volume fraction of grain

Table 1. Sputtering yield for $\mathrm{Cu}$ and $\mathrm{Ni}$ with the different average grain size $\left(\mathrm{Ga}^{+}, 30 \mathrm{keV}\right)$. The depth values indicated by number "1" are sputtered at $2.7 \mathrm{nA}$, by number " 2 " - at $0.8 \mathrm{nA}$.

\begin{tabular}{|c|c|c|c|c|c|}
\hline Metal & $\begin{array}{c}\mathrm{NS}-\mathrm{Cu} \\
d=260 \mathrm{~nm}\end{array}$ & $\begin{array}{c}\mathrm{Cu} \\
d=180 \mu \mathrm{m}\end{array}$ & $\begin{array}{c}\mathrm{NS}-\mathrm{Ni} \\
d=180 \mathrm{~nm}\end{array}$ & $\begin{array}{c}\mathrm{Ni} \\
d=5 \mu \mathrm{m}\end{array}$ & $\begin{array}{c}\mathrm{Ni} \\
d=30 \mu \mathrm{m}\end{array}$ \\
\hline Depth, $\mathrm{nm}$ & $480^{1} \pm 50$ & $1100^{1} \pm 300$ & $120^{2} \pm 30$ & $250^{2} \pm 100$ & $1000^{1} \pm 300$ \\
\hline$Y$, atom/ion & $2.1 \pm 0.2$ & $4.9 \pm 1.3$ & $2.0 \pm 0.5$ & $4.1 \pm 1.6$ & $4.8 \pm 1.5$ \\
\hline
\end{tabular}




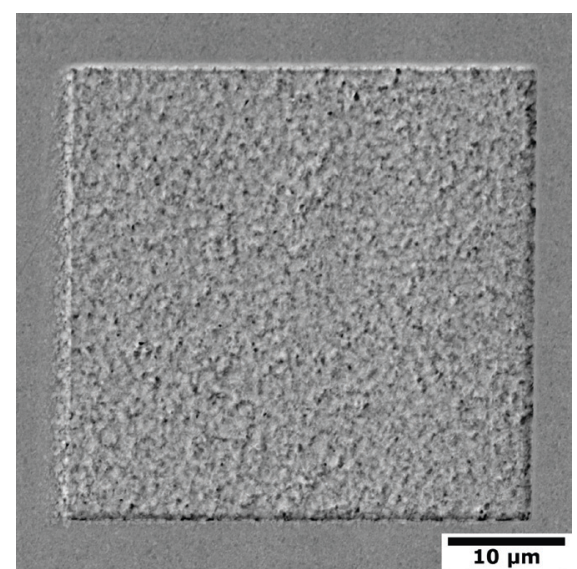

a

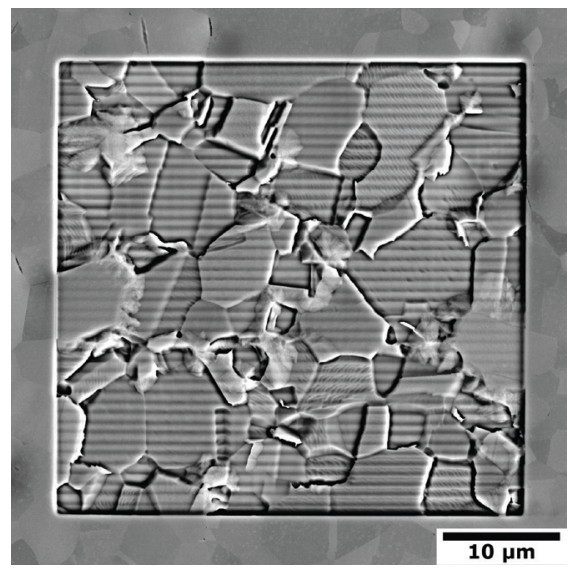

d

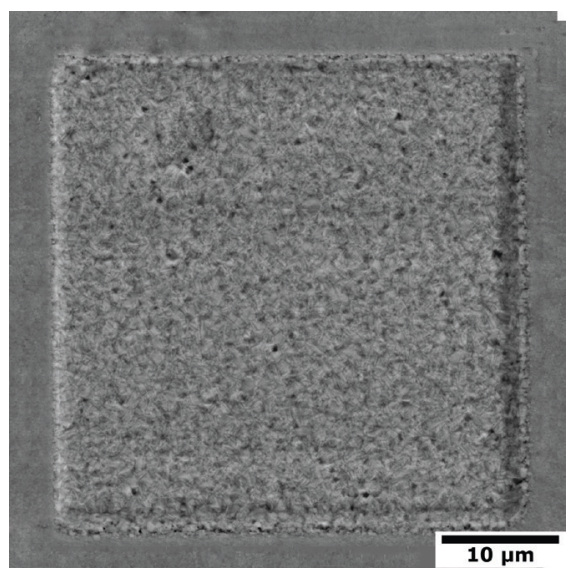

b

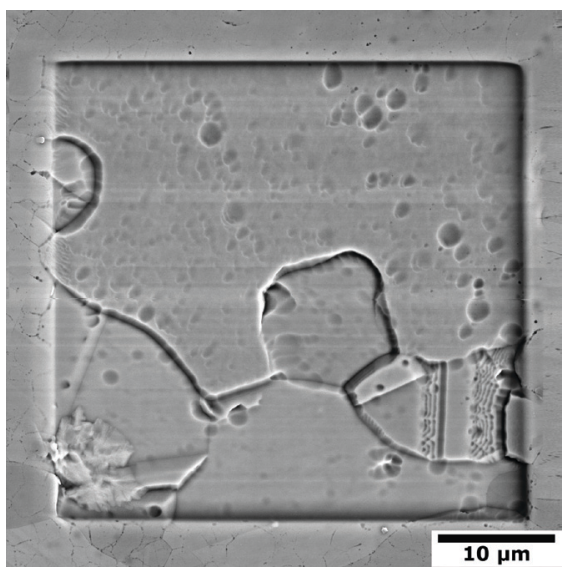

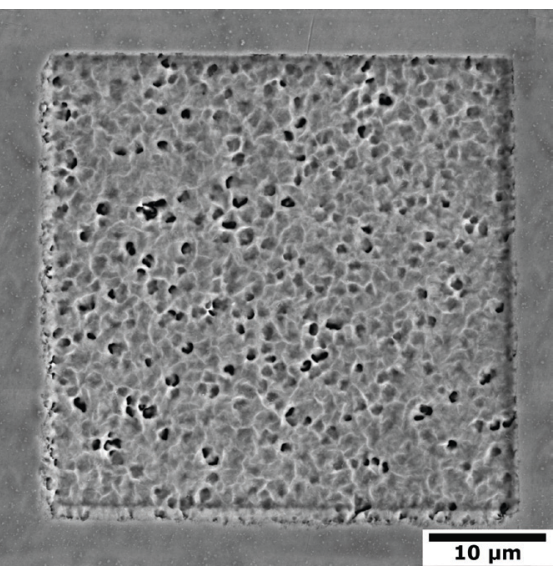

C

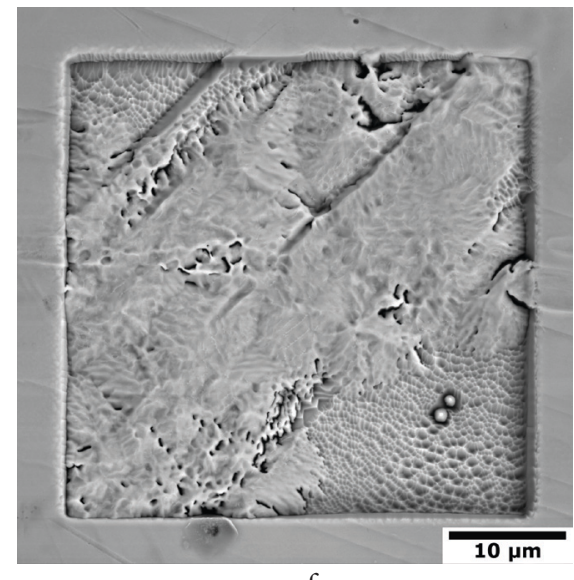

$\mathrm{f}$

Fig. 2. Secondary electron microscopy images of the surface after FIB machining: NS-Ni $(d=180 \mathrm{~nm})(\mathrm{a}), \mathrm{NS}-\mathrm{Ni}(d=300 \mathrm{~nm})(\mathrm{b})$, NS-Cu $(d=260 \mathrm{~nm})(\mathrm{c})$, fine-grained $\mathrm{Ni}(d=5 \mu \mathrm{m})(\mathrm{d})$, coarse-grained $\mathrm{Ni}(d=30 \mu \mathrm{m})(\mathrm{e})$ and coarse-grained $\mathrm{Cu}(d=180 \mu \mathrm{m})(\mathrm{f})$.
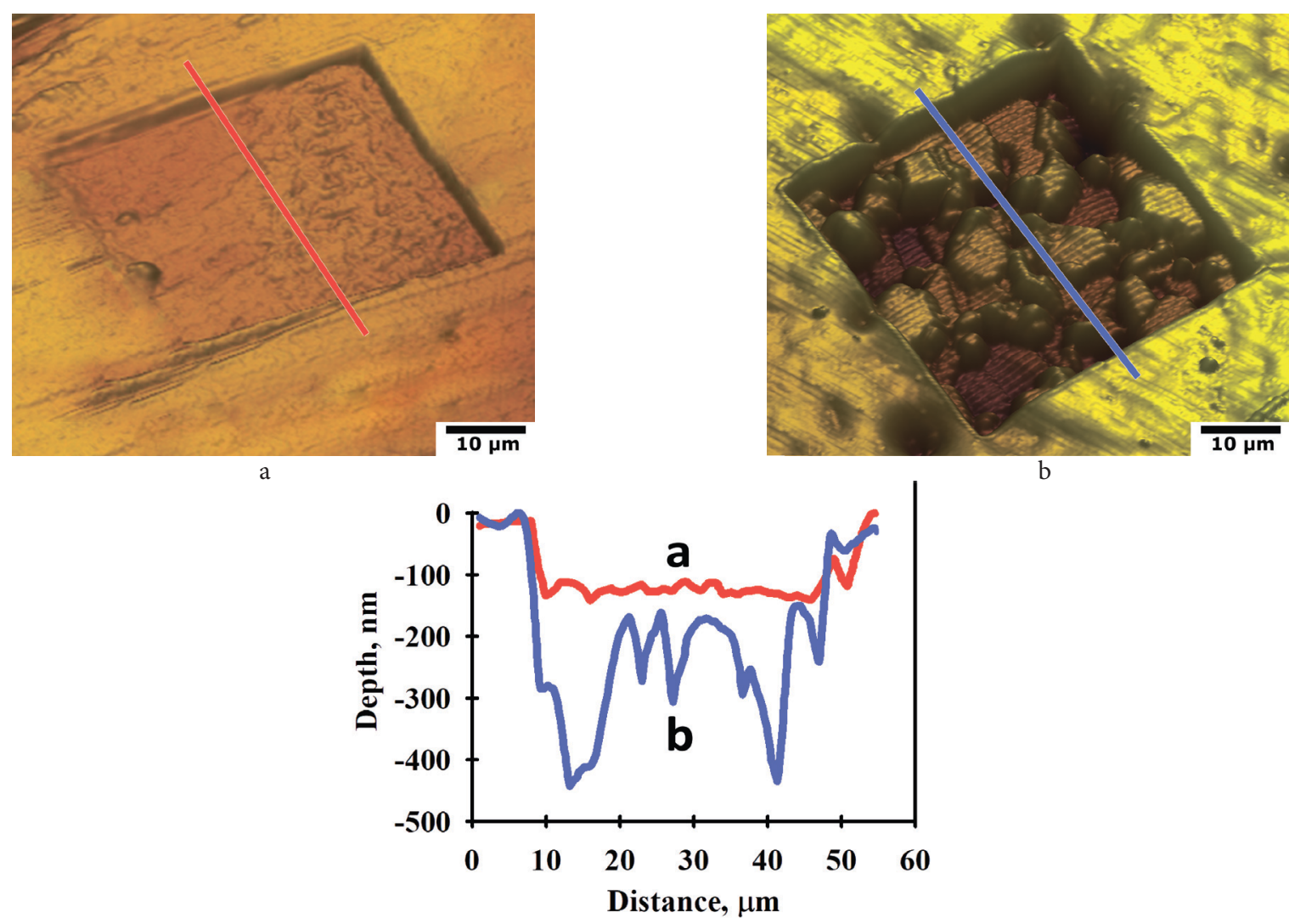

Fig. 3. (Color online) Scanning probe microscopy images of the surface after FIB machining for $30 \mathrm{keV} \mathrm{Ga}^{+}$at $0.8 \mathrm{nA}$ : nanostructured Ni $(d=180 \mathrm{~nm})(\mathrm{a})$, fine-grained $\mathrm{Ni}(d=5 \mu \mathrm{m})(\mathrm{b})$ and profiles $(\mathrm{c})$. 
boundaries. It can be expected that the displaced initial atoms, as well as secondary, etc. atoms "dissipate" their kinetic energy at defects and grain boundaries so that the efficiency of energy transfer in cascade collisions decreases. As a result, a certain number of displaced atoms do not reach the metal surface. In the case of a fine-grained or coarse-grained metal, where the concentration of defects and the volume fraction of grain boundaries are lower than in a nanostructured metal, the "kinetic energy" sputtering on crystalline defects is lower, respectively, the efficiency of the energy transfer in cascade collisions is higher. The number of atoms reaching the surface during ion bombardment (sputtering atoms) for a fine-grained or coarse-grained metal will be greater than for an NS metal. Accordingly, the sputtering yield of an NS metal will have a lowered value.

\section{Conclusions}

The effect of deformation nanostructuring of fcc metals - copper and nickel on ion sputtering by the FIB method with gallium ions with an energy of $30 \mathrm{keV}$ has been investigated. It is shown that the relief formed on the metal surface during the action of a focused ion beam depends on the grain size of the metal. On coarse-grained and fine-grained metals, the surface is sputtered unevenly with a relief height $R_{\max }$ of the order of several hundred nanometers. On the surface of a nanostructured metal, sputtering occurs relatively evenly with the height of the relief $R_{\max }$ of the order of several tens of nanometers. For an energy of $30 \mathrm{keV}$, the dependence of the relief height $R_{\max }$ on the grain size $d$ in the range from nanostructured to fine-grained is established: $R_{\text {max }} \approx 0.1 d$.

Measurements of profilograms of the sputtered areas showed that the average depths of the areas for samples with different grain sizes vary. The average depth of the sputtered areas on NS samples is lower than the average depth of areas on fine-grained and coarse-grained samples.

The ion sputtering yields of nickel and copper with different grain sizes are determined. The sputtering yield of nanostructured nickel with a grain size of $180 \mathrm{~nm}$ and nanostructured copper with a grain size of $260 \mathrm{~nm}$ is $2.0 \pm 0.5$ and $2.1 \pm 0.2$ atom/ion, respectively. The sputtering yield of fine-grained nickel with a grain size of $5 \mu \mathrm{m}$ is $4.1 \pm 1.6$ atom/ion, coarse-grained nickel with a grain size of $30 \mu \mathrm{m}$ and coarse-grained copper with a grain size of $180 \mu \mathrm{m}$ is $4.8 \pm 1.5$ and $4.9 \pm 1.3$ atom/ion, respectively.

Ion sputtering of the metal at an energy of bombarding ions of $30 \mathrm{keV}$ occurs in the linear cascade collision regime. The decrease in the ion sputtering yield of a nanostructured metal is due to the high concentration of defects and an increased volume fraction of grain boundaries in it, which reduce the efficiency of cascade collisions.

Acknowledgments. The study of the influence of the average grain size in nickel on the ion sputtering yield was carried out with the support of the Program \#16 of the Presidium of the Russian Academy of Sciences "Development of physical and chemical mechanics of surface phenomena as the fundamental basis for the development of modern structures and technologies." The study of the effect of copper nanostructuring on the ion sputtering yield was carried out with the support of a grant from the Republic of Bashkortostan to young scientists and young research teams. The study of the relief formed on the surface of metals during the action of a focused ion beam was carried out within the framework of the state assignment of the IMSP RAS No.AAAA-A17-117041310213-0. Electron microscopic studies were carried out on the basis of the Center of Collective Usage of Scientific Equipment of IMSP RAS "Structural and physico-mechanical studies of materials."

\section{References}

1. G. V. Gordeeva, M.I. Guseva, E.S. Ionova, M. E. Evemenenko. Soviet Atomic Energy. 68, 275 (1990). Crossref

2. C.A. Michaluk. Journal of Electronic Materials. 31, 2 (2002). Crossref

3. H. Hosokawa, K. Shimojima, H. Iwasaki, M. Mabuchi. Philosophical Magazine Letters. 84, 713 (2004). Crossref

4. I. Baranov, A. Brunelle, S. Della-Negra. Nuclear Instruments and Methods in Physics Research B. 193, 809 (2002). Crossref

5. V. Amirkhanov, Yu.N. Cheblukov, A.Yu. Didyk, A. Hofman et al. Physics of Particles and Nuclei. 37, 837 (2006). Crossref

6. H.S. Huang, C.H. Chiu, I.T. Hong, H.C. Tung, F. S.-S. Chien. Materials Characterization. 83, 68 (2013). Crossref

7. S. Flege, R. Hatada, T. Kaiser et al. Materials letters. 164, 532 (2016). Crossref

8. K.A. Tolpin, K. F. Minnebaev, V.E. Yurasova. Vacuum. 138, 139 (2017). Crossref

9. T. Nagasaki, H. Hirai, M. Yoshino, T. Yamada. Nuclear Instruments and Methods in Physics Research B. 418, 34 (2018). Crossref

10. A.A. Nazarov, R.R. Mulyukov. Nanostructured Materials. In: Handbook of NanoScience, Engineering and Technology. Ed. by W. A. Goddard III, D. Brenner, S.E. Lyshevski, G. J. Iafrate. CRC Press, Boca Raton (2002) P. 22-1-22-41. Crossref

11. R. Kh. Khisamov, I.M. Safarov, R.R. Mulyukov et al. Technical Physics. 56, 1661 (2011). Crossref

12. R. Kh. Khisamov, I.M. Safarov, R.R. Mulyukov, Yu. M. Yumaguzin. Physics of the Solid State. 55, 1 (2013). Crossref

13. K.S. Nazarov, R. Kh. Khisamov, Yu.M. Yumaguzin, R. R. Mulyukov. Technical Physics Letters. 41, 16 (2015). Crossref

14. R.Kh. Khisamov, K.S. Nazarov, I.M. Safarov, I. I. Musabirov, Yu.M. Yumaguzin, R.R. Mulyukov. Materials Physics and Mechanics. 33, 161 (2017). (in Russian) [Р.Х. Хисамов, К. С. Назаров, И.М. Сафаров, И.И. Мусабиров, Ю.М. Юмагузин, Р.Р. Мулюков. Физика и механика материалов. 33, 161 (2017).] Crossref

15. R. K. Khisamov, K. S. Nazarov, L. R. Zubairov et al. Physics of the Solid State. 57, 1206 (2015). Crossref

16. R. K. Khisamov, K. S. Nazarov, S. N. Sergeev, R. R. Kabirov, R. R. Mulyukov, A.A. Nazarov. Letters on Materials. 5, 119 (2015). (in Russian) [Р. Х. Хисамов, К. С. Назаров, 
С.Н. Сергеев, Р.Р. Кабиров, Р.Р. Мулюков, А.А. Назаров. Письма о материалах. 5, 119 (2015).] Crossref

17. I.Sh. Valeev, A.Kh. Valeeva, R.R. Mulyukov, R. Kh. Khisamov. Letters on Materials. 6, 347 (2016). (in Russian) [А.Х. Валеева, И.Ш. Валеев, Р.Р. Мулюков, P.Х. Хисамов. Письма о материалах. 6, 347 (2016).] Crossref

18. R. Kh. Khisamov, K.S. Nazarov, S.N. Sergeev, R. U. Shayakhmetov, J.A. Baimova, Y.M. Yumaguzin, R. R. Mulyukov. IOP Conference Series: Materials Science and Engineering. 447, 012001 (2018). Crossref

19. V.N. Danilenko, S.N. Sergeev, J.A. Baimova, G.F. Korznikova, K.S. Nazarov, R. K. Khisamov, A. M. Glezer, R. R. Mulyukov. Materials Letters. 236, 51 (2019). Crossref

20. K. Ohya, T. Ishitani. Surface and Coatings Technology. $158-159,8$ (2002). $\underline{\text { Crossref }}$

21. E. Horvath, A. Nemeth, A.A. Koos, M.C. Bein, A. L. Toth, Z. E. Horv, L. P. Bir, J. Gyulai. Superlattices and Microstructures. 42, 392 (2007). Crossref

22. H. Ostadi, K. Jiang, P.D. Prewett. Microelectronic Engineering. 86, 1021 (2009). Crossref

23. N.I. Borgardt, R.L. Volkov, A.V. Rumyantsev,
Yu. A. Chaplygin. Technical Physics Letters. 41, 610 (2015). Crossref

24. O.P. Landeros, N. Nedev, M.C. Alvarez et al. Vacuum. 157, 166 (2018). Crossref

25. F. Archie, M.Z. Mughal, M. Sebastiani, E. Bemporad, S. Zaefferer. Acta Materialia. 150, 327 (2018). Crossref

26. F. Baxter, A. Garner, M. Topping, H. Hulme, M. Preuss, P. Frankel. Journal of Nuclear Materials. 504, 176 (2018). Crossref

27. J. A. Taillon, C. Pellegrinelli, Y.-L. Huang, E. D. Wachsman, L. G. Salamanca-Riba. Ultramicroscopy. 184, 24 (2018). Crossref

28. M. Pea, G. Barucca, A. Notargiacomo, L. Di Gaspare, V. Mussi. Applied Surface Science. 433, 899 (2018). Crossref

29. Ed. by R. Behrisch, W. Eckstein. Sputtering by Particle Bombardment. Springer-Verlag, Berlin, Heidelberg. (2007) 509 p. $\underline{\text { Crossref }}$

30. N.N. Andrianova, A.M. Borisov, E.S. Mashkova, A. A. Shemukhin, V.I. Shulga, Yu.S. Virgiliev. Nuclear Instruments and Methods in Physics Research. B. 354, 146 (2015). Crossref

31. C. Volkert, A. Minor. MRS Bulletin. 32, 389 (2007). Crossref 